\title{
Strengthening Social Capital Through Social Economic Mitigation Based on Local Wisdom
}

\author{
Tetep Maskur ${ }^{1, *}$ Asep Supriatna ${ }^{2}$
}

\author{
${ }^{1}$ Institut Pendidikan Indonesia \\ ${ }^{2}$ Institut Pendidikan Indonesia \\ *Corresponding author. Email: tetep@institutpendidikan.ac.id
}

\begin{abstract}
The Covid 19 pandemic has weakened communal power and the world economy. Various countries have taken various ways to save the current socio-economic situation. Using a qualitative approach, this research was carried out to analyze a model for strengthening social capital in Garut, Indonesia, through socio-economic mitigation based on local wisdom. To this end, a survey was carried out in 5 sub-districts in Garut. The results showed that people in these areas find it difficult to maintain a social distance because they feel they belong to one community. Strengthening social capital is not done by social and physical distancing, but by getting to know the citizens themselves, and if there are, newcomers are recommended to introduce themselves to the local government. That way, economic activities in the area can run as usual so that the pandemic is not so feared, but social values and community togetherness are maintained. Only those who are affected economically are residents who migrate and work outside the city. Thus, with the social capital and local wisdom they have, they can mitigate their socio-economic environment.
\end{abstract}

Keywords: Social Capital, Socioeconomic Mitigation, Local Wisdom

\section{INTRODUCTION}

COVID-19 is a disease caused by the severe acute respiratory syndrome coronavirus 2 (SARS-CoV-2). COVID-19 can cause respiratory system disorders, ranging from mild symptoms such as flu to lung infections, such as pneumonia. The first case of this disease occurred in Wuhan, China, at the end of December 2019. In just a few months, COVID-19 spread from person to person very quickly to dozens of countries, including Indonesia. Several countries went into lockdowns to prevent the spread of the Coronavirus. The Indonesian government has implemented a LargeScale Social Restriction (PSBB) policy to suppress this virus's spread. Of all who died from COVID-19, $1 \%$ were aged $0-5$ years, $15.2 \%$ were aged $31-45$ years, $39.4 \%$ were aged $46-59$ years, and $38.6 \%$ were aged 60 years and over. Meanwhile, based on gender, $59.1 \%$ of those who died from COVID-19 were male, and the remaining $40.9 \%$ were women [1].

Most people infected with the COVID-19 virus will experience mild to moderate respiratory illness and recover without requiring special treatment. Older people and those with underlying medical problems such as cardiovascular disease, diabetes, chronic respiratory disease, and cancer are more likely to develop serious illnesses (WHO). Of course, the Covid - 19 virus's impact is not only affecting the world in terms of health but also socio-economic aspects. When a lockdown policy is imposed, people are required to remain in their respective homes to mitigate further transmission rates. However, this policy is, of course, very influential, especially in the economic sector. The lockdown affects several economic sectors, including 1) Tourism. When a country goes into a lockdown, a country will prohibit tourists, both domestic and foreign, from leaving its area of origin. This resulted in a reduced source of foreign exchange. This policy has also caused the aviation industry to experience sluggishness. 2) Manufacture, obstruction of the supply chain due to the lockdown policy's implementation resulting in scarcity of basic materials and several companies implementing layoffs. 3) Labor, the labor sector experiences problems because companies and firms stop production, and this results in decreasing people's income from wages and the informal sector. This 
affects people's purchasing power, which should remain normal when an outbreak occurs [1].

Covid-19 has also affected the finances, including the Indonesian rupiah. One of the reasons for the depreciation of the Rupiah in the future is because money market players and investors are withdrawing their money and investment from developing countries such as Indonesia. Forex players move their assets to the dollar, which is a haven so that the rupiah weakens. The shift in value to gold is also the reason why some world currencies have weakened. Another reason is that the rupiah weakened shortly after the State Budget (APBN) deficit and sentiment from the increasing number of victims of the coronavirus in Indonesia. Exports have been disrupted, and the country's foreign exchange income from tourism has also decreased, causing Rupiah to depreciate. We need to know that the tourism sector is the second largest contributor to foreign exchange (CNBC Indonesia), and tourism can strengthen the rupiah because foreign tourists will inevitably use the rupiah. Covid-19 has an impact on lower, middle, and upperclass society. During the pandemic, social capital is needed through socio-economic mitigation based on local wisdom. [2].

Social capital is a characteristic, such as beliefs, norms, and social networks that social organizations have to improve people's lives through organized activities [3]. Social capital is the totality of all actual or real resources increasing in number to individuals or groups related to the expansion of the social network they do [4]. Social capital is an informal norm that encourages human relations between two or more people. Human relations are based on informal norms in a close relationship, and the relationship is reciprocal [5]. Social capital is a social rule that holds people together in their life activities. In this case, social rules are in line with the functioning of the community's culture. Social rules underlie feelings of belonging about society's existing culture, and social rules underlie feelings of acceptance in their social life [6]. Besides, social capital is a tool for resolving conflicts in society and contributes to social integration. In fact, social capital can form community social solidarity with the pillar of volunteerism and build community participation. As a pillar of democracy, social capital can be an instrument for bargaining with the government.

Social capital is the glue of interpersonal connections through platforms, such as institutions or social networks. [7] Shared behavioral norms act as a social order that underlies their social life. This social relationship is also strengthened by cultural identifications as a binding to the sense of belonging, so that sustainability, unity, and togetherness are maintained. All of that is aimed at achieving social welfare as a common goal. Now in its development, social capital can cement and unite the social relations of individuals, groups, communities, including the rice farming community.
At the sociological level, social capital is norms. There is a reciprocal relationship and mutual trust between two or more parties that can be manifested in a very close relationship (friendship) instead of a formal relationship, aiming to achieve mutual social welfare. As the glue of community social relations, social capital includes cultural wisdom, values, cooperation, mutual trust, and social networks.

The term social capital actually refers to an individual's capacity to acquire material or symbolic goods of value based on the virtue of social relationships and membership in social groups of the plurality of a person to enjoy the benefits of collective action based on the virtue of social participation, trust in institutions or commitment to determining ways of doing things [8]. Social capital is the ability of actors to guarantee benefits by relying on membership in social networks and other social structures [9]. Social capital is the degree of social cohesion that exists in a community. It refers to the processes between people that build networks, norms, and social trust and facilitate mutually beneficial coordination and cooperation [10]. Social capital generally refers to stocks of social trust, norms, and networks that society can use to solve common problems [11]. Social capital as a whole is aimed to facilitate individual action in its social structure. Physical capital refers to physical objects, human capital refers to individual property, and social capital refers to the relationships between individuals, social networks, and the norms of reciprocity and beliefs that arise from them [12]. Social capital can increase or decrease from time to time [13].

Socio-economic status refers to a family's financial ability and material equipment, where this condition is of the good, adequate, and insufficient standard [14]. The socio-economic review of the population includes social aspects, socio-cultural aspects, and village aspects related to institutional and job opportunities. Village economic aspects and job opportunities are closely related to the problems of the welfare of rural communities. Sufficient food and economic needs for the community will only be reached if their household income is sufficient to cover household needs and their businesses' development [15]. This is determined by the ownership of the land, capital, technology, and land size [16]. The socio-economic condition is a position that rationally determines a person in a certain position in society. The granting of such a position is accompanied by a set of rights and obligations that must be played by the status bearer [17]. The socioeconomic condition characteristics include educational background, health, employment, and self-awareness of the environment, mobility rate, land size, and so on. The socio-economic aspects of the village and job opportunities are closely related to the problems of the village community's welfare. 
Local wisdom refers to the various cultural properties that develop in a society. Local wisdom is recognized as an important element capable of strengthening social cohesion in society [18]. Quaritch Wales defines local wisdom or local genius as "the sum of the cultural characteristic that the vast majority of a people have in common due to their experiences in early life." The main ideas contained in the definition are (1) cultural character, (2) cultural group, and (3) life experience born from cultural character. Local wisdom is extracted from cultural products related to life and community, such as value systems, beliefs and religions, work ethics, and dynamics [19]. Local wisdom refers to knowledge, beliefs, understandings, and customs or ethics that guide human behavior in the ecological community. Thus it can be concluded that local wisdom is a cultural value in the local community in the form of traditions, culture, and motto that functions to regulate social order. In this case, local wisdom is highly valued and has great benefits in people's lives. However, these values are usually only attached to people who still uphold customs and culture [20].

\section{METHODS}

This research was conducted using a descriptive qualitative approach. The selection of this approach is to gain descriptive data of aspects of strengthening social capital and efforts to overcome socio-economic mitigation based on local wisdom. Research samples were university students doing their online community service program at 5 subdistricts in Garut, such as Sukaresmi, Pameungpeuk, Bayongbong, Bungbulang, Wanaraja. These samples were selected based on their place of residence. Data analysis was performed using the triangulation technique, which verified data and information obtained by comparing them with theoretical references, research methods, and opinions between researchers

\section{RESULTS AND DISCUSSION}

Strengthening social capital can encourage socioeconomic mitigation based on local wisdom in Garut. Therefore, the discussion will focus on strengthening the social capital of the community in 5 sub-districts in Garut there are Sukaresmi, Pameungpeuk, Bayongbong, Bungbulang, Wanaraja, through student participation in online community service program:

1. Strengthening community social capital in dealing with the Covid-19 pandemic in 5 sub-districts in Garut Regency is focused on understanding social distancing. This is difficult to implement because they feel they are still in one day with the community, and if there is a newcomer, they inform local administrators.

2. Strengthening social capital in 5 sub-districts in Garut aims to increase their own capacity to understand social rules, health protocols, implementing the new normal, and Covid-19 prevention. Strengthening social capital was carried out through counseling, mentoring, community guidance, and socialization by students as Covid volunteers and related agency task forces by involving the community and local community leaders, both formally and informally. Through outreach and other similar activities, the community understands and lives social capital values to be implemented in their social environment [21]. Strengthening social capital is facilitated and guided by local administrators and the Health Service through the Garut Covid Task Force.

The term social capital actually refers to an individual's capacity to acquire material or symbolic goods of value based on the virtue of social relationships and membership in social groups or the plurality of a person to enjoy the benefits of collective action based on the virtue of social participation, trust in institutions or commitment to determining ways of doing things [8]. Social capital is the ability of actors to guarantee benefits by relying on membership in social networks and other social structures [9]. Social capital is the degree of social cohesion that exists in a community. It refers to the processes between people that build networks, norms, and social trust and facilitate mutually beneficial coordination and cooperation [10]. Social capital generally refers to stocks of social trust, norms, and networks that society can use to solve common problems [11]. Social capital as a whole is aimed to facilitate individual action in its social structure. Physical capital refers to physical objects, human capital refers to individual property, and social capital refers to the relationships between individuals, social networks, and the norms of reciprocity and beliefs that arise from them [12]. Social capital can increase or decrease from time to time [13].

3. Coordination between village administrations with the community in 5 sub-districts in Garut is an important effort to unite, bring together all parties involved, and achieve common goals. The role of village administration, task force, and volunteers, as well as students, in this case, is crucial to find solutions and prevent the spread of Covid-19. Such cooperation is established through a good cooperative network and mutual trust. All of this becomes the glue of social relations and communication to strengthen the postCovid socio-economic conditions. Local wisdom refers to society. That the Local wisdom recognized as important elements capable of strengthening social cohesion in society [18]. Quaritch Wales defines local wisdom or local genius as "the sum of the cultural characteristic that the vast majority of a people have in common due to their experiences in early life." The main ideas contained in the definition are (1) cultural character, (2) cultural group, and (3) life experience born from cultural character. Local wisdom is extracted from cultural products related to life and community, such as 
value systems, beliefs and religions, work ethics, and dynamics [19]. Local wisdom refers to knowledge, beliefs, understandings, and customs or ethics that guide human behavior in the ecological community. Thus it can be concluded that local wisdom is a cultural value in the local community in the form of traditions, culture, and motto that functions to regulate social order. In this case, local wisdom is highly valued and has great benefits in people's lives. However, these values are usually only attached to people who still uphold customs and culture [22].

4. Socio-economic mitigation based on local wisdom in Garut. Disaster mitigation is a series of efforts carried out by related agencies together with the community to reduce disaster risk, both through the construction of physical facilities and increasing awareness (Article 1 Paragraph 6 of Regulation Government of Republic of Indonesia No. 21 of 2008 on Disaster Management) [23] in overcoming the Covid-19 problem and its impact on the community's economy and food security to form resilient villages. Counseling is concerned with awareness efforts regarding the application of health protocols, prevention of Covid-19, and its impact for the sake of global survival. Socioeconomic status refers to a family's financial ability and material equipment, where this condition is of the good, adequate, and insufficient standard [14]. The socioeconomic review of the population includes social aspects, socio-cultural aspects, and village aspects related to institutional and job opportunities. Village economic aspects and job opportunities are closely related to the problems of the welfare of rural communities. Sufficient food and economic needs for the community will only be reached if their household income is sufficient to cover household needs and their businesses' development [15]. This is determined by the ownership of the land, capital, technology, and land size [16]. The socio-economic condition is a position that rationally determines a person in a certain position in society. The granting of such a position is accompanied by a set of rights and obligations that must be played by the status bearer [17]. The socioeconomic condition characteristics include educational background, health, employment, and self-awareness of the environment, mobility rate, land size, and so on. The socio-economic aspects of the village and job opportunities are closely related to the problems of the village community's welfare.

Based on the above-mentioned description, it could be said that people in the studied area find it difficult to keep social distancing because they feel they belong to one community, and if there are any newcomers from outside, they inform the local administrations. Strengthening social capital is not done by maintaining social and physical distance but by getting to know each other, and newcomers are recommended to report themselves to the local government. That way, economic activities in the area can run as usual. Only those who are affected economically are residents who migrate and work outside the city. Thus, with the social capital and local wisdom they have, they can mitigate their socioeconomic environment.

\section{CONCLUSION}

Based on the results of the study, it could be concluded that: 1) Strengthening social capital in 5 subdistricts in Garut is aimed at increasing their own capacity on understanding social rules, health protocols, implementing the new normal and Covid-19 prevention and is facilitated and guided by local administrators and the Health Service through the Garut Covid Task Force. 2) Coordination between village administrations with the community in 5 sub-districts in Garut is an important effort to unite, bring together all parties involved, and achieve common goals. 3) Socio-economic mitigation based on local wisdom in Garut aims to overcome Covid19 related problems and their impact on the community's economy and food security. 4) people in the studied area find it difficult to keep social distancing because they feel they belong to one community, and if there are any newcomers from outside, they inform the local administrations. Strengthening social capital is not done by maintaining social and physical distance but by getting to know each other, and newcomers are recommended to report themselves to the local government. That way, economic activities in the area can run as usual. Only those who are affected economically are residents who migrate and work outside the city. Thus, with the social capital and local wisdom they have, they can mitigate their socio-economic environment.

\section{REFERENCES}

[1] Merry Dame Cristy Pane. "COVID-19". Accessed on Aug 14, 2020. [Online]. Available: https://www.alodokter.com/covid-19.

[2] Al Ikhsan, Mochammad, "Covid-19 dan Mitigasi Kebijakan Moneter dan Fiskal", 2020. Accessed on Aug 14, 2020. [Online]. Available: https://www.researchgate.net/publication/3409529 85_Covid19_dan_Mitigasi_Kebijakan_Moneter_dan_Fiskal

[3] Robert Putnam, "Social Capital". Princeton University. Princeton. 1993

[4] Bourdieu, Pierre, and Wacquant, Loic J. D., An Invitation to Reflexive Sociology, Chicago: University of Chicago Press, 1992

[5] Fukuyama, F. Guncangan besar. Kodrat Manusia dan Tata Sosial Baru. PT.Gramedia Pustaka Utama. Jakarta, 2005 
[6] Dasgupta et al., (2012). Effects of Meal Preparation Training on Body Weight,Glycemia, and Blood Pressure: Results of a Phase 2 Trial in Type 2Diabetes. International Journal of Behavioral Nutrition and PhysicalActivity 2012, 9:125.

[7] Asri Sulistiawati, Djuara P Lubis, Eko Sri Mulyani. (2014). Analisis jaringan sosial dalam gabungan Kelompok tani (gapoktan) tani berkah. https://journal.ipb.ac.id/index.php/sodality/article/d ownload/9415/7378.

[8] Fathy, Rusydan. 2017. Modal Sosial dan Ketahanan Ekonomi Ojek Pangkalan Salemba. Skripsi. Jakarta: Universitas Islam Negeri Syarif Hidayatullah.

[9] Portes, A. (1998). Social Capital: Its Origins and Applications in Modern Sociology. Annual Review of Sociology.

[10] Woolcock, M. (1998). Social Capital and Economic Development:Toward A Theoretical Synthesis and Policy Framework. Theory and Society, 27(2), 151208. DOI: https://doi.org/10.1023/A:1006884930135 .

[11] Lang, Robert T., dan Steven P. Hornburg, 1998. What is Social Capital and Why Is it important to Public Policy, Housing Policy Debate, Volume 9, Issue 1, Fannie Mae Foundation.

[12] Coleman, James, S., "Social Capital in Creation of Human Capital". University of Chicago Press, 1989.

[13] Field, John, Modal Sosial. Terjemahan Nurhadi. Bantul: Kreasi Wacana, 2010

[14] Agus Salim. (2002). "Perubahan sosial. Yogyakarta”, Yogyakarta, Tiara Wacan, 2002.

[15] Basrowi dan Siti Juariyah (2010). Analisis kondisi sosial ekonomi dan tingkat pendidikan masyarakat desa Srigading, kecamatan Labuhan Maringgai,kabupaten Lampung Timur. 2010, Accessed on Aug 14, 2020. [Online]. Available https://jurnal.ugm.ac.id/jps/article/download/47463 /pdf .

[16] Sajogyo. "Sosiologi Pedesaan". Yogyakarta. Gadjah Mada Press, 2005

[17] Sumardi, Mulyanto dan Dieter - Evers, "Kemiskinan dan Kebutuhan pokok". Jakarta: Rajawali, 2000

[18] Maria Matildis Banda. 2020. Upaya Kearifan Lokal dalam Menghadapi Tantangan Perubahan Kebudayaan. Accessed on Aug 14, 2020. [Online]. Available https://simdos.unud.ac.id/uploads/file_penelitian_1 _dir/094c38353e4aaa6691067abdc34c1d5c.pdf

[19] Sibarani, Robert. 2012. "Foklore sebagai Media dan Sumber Pendidikan: Sebua Ancangan Kurikulum dalam Pembentukan Karakter Siswa Berbasis Nilai Budaya Batak" dalam Kearifan Lokal. Hakekat, Peran, dan Metode Tradisi Lisan. Yogyakarta: Penerbit Lontar, 2012.

[20] Tetep, et.al.,Social Capital and Entrepreneurial Motives among Students in East Preanger Indonesia. Proceedings of the 4th Global Conference on Business Management \& Entrepreneurship (GC-BME 4), Aug, 82019 , Bandung, Indonesia. ISBN 9780367674717 Published December 8, 2020, CRC Press [Online]. Available: https://www.routledge.com/Advancesin-Business-Management-and-EntrepreneurshipProceedings-of-the/Hurriyati-Tjahjono-AbdullahSulastri-Lisnawati/p/book/9780367674717.

[21] Pranadji, Tri. 2009. Penguatan Kelembagaan Gotong Royong Dalam Perspektif Sosio Budaya Bangsa: Suatu Revitalisasi Adat Istiadat Dalam Peneyelenggaraan Pemerintahan. Forum Penelitian Agro Ekonomi. Volume 27. No.1, Juli 2009: 61-27.

[22] Tetep, Eldi Mulyana, Triani Widyanti, Ade Suherman. (2020) Nation Character Building for Millennial Generation Based on Local Wisdom of Saminism. Accessed on Aug 14, 2020. [Online]. Available: https://www.atlantispress.com/proceedings/icssgt-19/125942802.

[23] Sudirah, Agus Susanto, Sumartono, Muhammad Syukur (2020). Hubungan Penguatan Modal Sosial, Mitigasi Bencana Banjir dan Peningkatan Produksi Pertanian. Accessed on Aug 14, 2020. [Online]. Available:https://journal.unismuh.ac.id/index.php/ equilibrium/article/download/3094/2356 